\title{
Blood biochemical indicators and concentration of thyroid hormones in heavily pregnant and lactating ewes depending on selenium supplementation
}

\author{
Josip Novoselec ${ }^{1}$, Marcela Šperanda ${ }^{1}, Z_{\text {Zeljka Klir }}^{1}$, Boro Mioč ${ }^{2}$, \\ Zvonimir Steiner ${ }^{1}, Z_{\text {vonko Antunović }}^{1}$ \\ ${ }^{1}$ University of J.J. Strossmayer in Osijek, Faculty of Agriculture in Osijek, \\ Department for Animal Husbandry, Osijek, Croatia \\ ${ }^{2}$ University of Zagreb, Faculty of Agriculture Zagreb, \\ Department of Animal Science and Technology, Zagreb, Croatia
}

Received October 12, 2016

Accepted December 19, 2017

\begin{abstract}
The aim of this research was to determine the effect of dietary selenium supplementation (organic and inorganic) on the biochemical indices and thyroid hormone concentration in the blood of heavily pregnant and lactating ewes. Research was conducted on 30 pregnant ewes of the Merinolandschaf breed divided into 3 groups, and lasted for four months (two months on ewes in late pregnancy and two months on ewes during lactation). The first group was given a basal diet without the addition of selenium. The feed mixture of group 2 was supplemented with $0.3 \mathrm{mg} / \mathrm{kg}$ of organic sources of selenium, and group 3 with the same amount of inorganic sources of selenium. In lactating ewes, organic and inorganic selenium lead to a significant $(P<0.05 ; P<0.01)$ increase in urea concentration. At the same time, in lactating ewes inorganic selenium had a significant decreasing effect $(P<0.05 ; P<0.01)$ on cholesterol, lowdensity lipoprotein and triglycerides. Organic selenium in heavily pregnant ewes significantly $(P<0.01)$ increased aspartate aminotransferase activity in comparison to group 1 and 3 . In lactating ewes significant $(P<0.05)$ differences in aspartate aminotransferase activity were determined between groups 2 and 3 . With selenium supplementation a significant $(P<0.01$; $P<0.05$ ) increase concentration of Se was determined (for heavily pregnant and lactating ewes, respectively), as well as $\mathrm{Na}, \mathrm{Cl}, \mathrm{Fe}$ (lactating ewes), and a decrease of $\mathrm{K}$ (high pregnant ewes). Organic selenium had an effect on the increase of triiodothyronine in lactating ewes. We can conclude that selenium supplementation contributes to good health and condition of ewes in the demanding period of lactation.
\end{abstract}

Health status, thyroxine, triiodothyronine, selplex, sodium selenite

The periparturient period, especially late pregnancy and early lactation are demanding periods in ewes' production life regarding their health status, production, and nutrition (Antunović et al. 2011). It is very important that the ewes' feed in these two periods is balanced in terms of nutrients and trace elements. Selenium (Se) is an essential trace element and its concentration in animal food must be appropriate. Disorders and diseases related to selenium deficiency lead to significant economic losses. Selenium deficiency most commonly causes fertility reduction, abortion and retained placenta in ewes, as well as health problems in young animals, such as increased neonatal mortality, lower vitality of new-born lambs, reduction of the suckling reflex, and frequent occurrence of lamb diseases. Selenium is one of the essential trace elements for normal thyroid hormone metabolism (Aurthor et al. 1992). Selenium is required for the conversion of thyroxine $\left(\mathrm{T}_{4}\right)$ into the more active triiodothyronine $\left(\mathrm{T}_{3}\right)$ via the enzyme type 4 deiodinase (Aw adeh et al. 1998; Sethy et al. 2015). Determining biochemical indices, thyroid hormone concentration, and

Address for correspondence:

Assistant Professor Josip Novoselec, Ph.D.

Department for Animal Husbandry

Faculty of Agriculture in Osijek

University of J.J. Strossmayer in Osijek

Vladimira Preloga 1, 31000 Osijek, Croatia

Phone: +38531 554906

E-mail: jnovoselec@pfos.hr

http://actavet.vfu.cz/ 
enzyme activity in the blood of animals gives us a clearer picture of the nutritional and health status, before the mentioned problems are even visible in the animal (Antunović et al. 2009). The Se concentration in the soil and therefore in the plants is low in many parts of the world including the area of the Pannonian Basin which Croatia is part of. Among the various methods of improving the Se concentration in animals, optimization of the Se content in feeds is the most important. The most commonly used inorganic selenium supplement in animal feeds is sodium selenite, and organic selenized yeast. According to research in ewes (Hall et al. 2012), true digestibility of Se from diets containing selenite showed to be about $50 \%$ whereas that from Se-yeast was about $66 \%$ with regard to different metabolism. Inorganic selenium is exclusively used for the synthesis of seleno-enzymes whereas organic selenium can be incorporated into any protein, serving as a possible Se storage capacity (Vignola et al. 2007). Previous studies have usually involved the determination of a smaller number of blood variables (Se, glutathione peroxidase) indicating the effects of Se addition to the diets of ewes and lambs (Faix ova et al. 2007). However, the addition of Se to the diets of animals may cause certain metabolic changes that may affect their productivity and health status (Salman et al. 2013; Antunović et al. 2013). Therefore, the aim of this manuscript was to study and compare the influence of sodium selenite and selenium yeast dietary supplement on the biochemical properties, thyroid hormone concentration, and enzyme activity in the blood of heavily pregnant and lactating ewes, and thereby to check their health and nutritional status.

\section{Materials and Methods}

The experimental protocol used in this research was approved by the Commission for Animal Welfare, Faculty of Agriculture, University of Josip Juraj Strossmayer in Osijek, Croatia.

\section{Design of experiment and treatments}

The study was conducted on 30 pregnant Merinolandschaf ewes. The ewes included in the study were selected from a flock of 200 animals. The selected ewes were of the mean age of four years, healthy, and in a good physical condition. The study was commenced in late autumn by selecting the pregnant ewes, and continued during the spring of the following year with ewes in lactation. Pregnancy was determined using ultrasound Tringa 50S (PIE Medical, Netherlands). The research included ewes in the last trimester of pregnancy. The research continued during a four month period, two months with ewes in the period of late pregnancy and two months with lactating ewes. The ewes were divided into three groups of 10 highly pregnant animals (the last trimester of pregnancy) and after lambing, into the same three groups of 10 ewes in lactation. The ewes within each group had their own feeding place. The control group of ewes (group 1) was given a feed consisting of $300 \mathrm{~g} / \mathrm{day} / \mathrm{animal}$ of a feed mixture without Se supplement, $150 \mathrm{~g} /$ day/animal of barley, and alfalfa hay which, like water, they had ad libitum. The feed mixture in group 2 was enriched with the addition of $0.3 \mathrm{mg} / \mathrm{kg}$ diet of organic selenium (Selplex ${ }^{\circledR}$, Alltech), and the feed mixture in group 3 by the same amount of inorganic selenium (sodium selenite). Ingredients and chemical composition of basal feed mixture is shown in Table 1 . The laboratory analysis of the basal feed mixture revealed the following quantities of dry matter (DM) of selenium: $0.092 \mathrm{mg} / \mathrm{kg}$ in the control group, 0.30 $\mathrm{mg} / \mathrm{kg}$ in group 2 , and $0.299 \mathrm{mg} / \mathrm{kg}$ in group 3 .

\section{Collection and analysis of blood samples}

Blood sampling was carried out in heavily pregnant ewes and ewes in lactation (on days -14 and 23 relative to parturition). Blood samples were collected from the jugular vein into a sterile vacuum tube Venoject ${ }^{\mathbb{B}}$ (Leuven, Belgium). Samples of blood for determination of biochemical indicators by centrifuge (ROTOFIX 32A) were centrifuged for $10 \mathrm{~min}$ at $1600 \times \mathrm{g}$ to separate the serum, and then frozen.

\section{Determination of biochemical indicators}

In the blood serum of ewes, concentrations of calcium $(\mathrm{Ca})$, inorganic phosphorus $(\mathrm{P})$, potassium $(\mathrm{K})$, sodium $(\mathrm{Na})$, chloride $(\mathrm{Cl})$, and iron $(\mathrm{Fe})$, biochemical indicators (glucose, urea, total cholesterol, triglycerides, total protein, globulin, albumin, HDL-cholesterol, LDL-cholesterol, and total bilirubin) and enzymes (AST, ALT, GGT, ALP, and CK) were determined. All minerals, biochemical indicators, and enzymes were determined using the biochemistry analyzer Olympus AU 400 (Olympus, Tokyo, Japan). 
Table 1. Ingredients and chemical composition of THE basal feed mixture

\begin{tabular}{lc}
\hline Ingredient & Dry matter $(\mathrm{g} / \mathrm{kg})$ \\
Corn & 511 \\
Wheat flour & 150 \\
Molasses & 40 \\
Yeast & 30 \\
Dehydrated alfalfa meal & 20 \\
Sunflower meal & 90 \\
Soybean meal & 90 \\
Animal salt & 4 \\
Limestone & 20 \\
Monocalcium phosphate & 10 \\
CMR** & 25 \\
Premix* & 10 \\
Chemical composition $(\mathrm{g} / \mathrm{kg} \mathrm{DM})$ & \\
Dry matter & \\
Crude protein & 880 \\
Crude fibre & 177 \\
Crude fat & 64 \\
Ash & 30 \\
Metabolizable energy $(\mathrm{MJ} / \mathrm{kg})$ & 70 \\
\hline CM & 11.2 \\
\hline
\end{tabular}

$\mathrm{DM}=$ dry matter; *1 kg of control premix contained vit. A=1 $000000 \mathrm{IJ}$; vit. D3 = $150000 \mathrm{IJ}$; vit. E=1500 mg; vit. $\mathrm{K} 3=50 \mathrm{mg}$; vit. $\mathrm{B} 1=100 \mathrm{mg}$; vit. $\mathrm{B} 2=200 \mathrm{mg}$; vit. B6=200 mg; vit. B12=1 mg; Ca panthotenate $=500$ $\mathrm{mg}$; niacin $=1000 \mathrm{mg}$; choline chloride $=20000 \mathrm{mg} ; \mathrm{FeSO}_{4}=4000 \mathrm{mg} ; \mathrm{CuSO}_{4}=800 \mathrm{mg} ; \mathrm{Mn}$ oxide $=3500 \mathrm{mg}$; $\mathrm{Zn}$ sulphate $=5000$; cobalt chloride $=20 \mathrm{mg} ; \mathrm{Mg}$ sulphate $=10000 \mathrm{mg}$; antiox. BHT $=10000 \mathrm{mg}$; potassium iodide $=80 \mathrm{mg} ; * *$ Complete milk replacer composition: skimmed milk powder, oils and fats (palm coconut oil), wheat starch, hydrolyzed wheat protein, calcium carbonate, dried egg powder, magnesium sulphate

\section{Selenium determination}

Selenium concentration was determined in the digested samples by electrothermal atomic absorption spectrometry with palladium as a matrix modifier and Zeeman background (AAnalyst 600, Perkin-Elmer Instruments, USA). In the ewes' milk, Se concentration was determined in the digested samples by graphite atomic absorption spectrophotometry with palladium nitrate and magnesium nitrate as matrix modifiers and Zeeman background correction (AAnalyst 800, Perkin-Elmer Instruments, USA).

Determination of thyroid hormones

The concentration of thyroid hormones in the blood serum of ewes was determined by the method for $\mathrm{T}_{3}$ MEI (Microparticle Enzyme Immunoassay), and $\mathrm{T}_{4}$ FPAI (Fluorescence Polarization Immunoassay) using the automatic immunoassay analyzer IMX-ABBOT (Abbott Laboratories, USA). The sensitivity of the method was less than $0.4 \mathrm{nmol} / 1$ for the $\mathrm{T}_{3}$, and $12.8 \mathrm{nmol} / 1$ for $\mathrm{T}_{4}$. The mean coverage rate was $98.6 \%$.

\section{Statistical analysis}

Research results were processed by the SAS (SAS Inst. Inc., Cary NC) software. Effects of treatment (group 1 - without selenium; group $2-0.3 \mathrm{mg} / \mathrm{kg}$ of organic selenium feed supplement; group $3-0.3 \mathrm{mg} / \mathrm{kg}$ of inorganic selenium feed supplement) on the concentration of biochemical indicators, thyroid hormone concentration and minerals in blood of ewes, were analyzed by two way repeated measures ANOVA. Where the analysis showed significant differences, Scheffe's test was performed. Results are presented as least square means with SEM and $P$-value. Statistical differences were declared at $P<0.05$. 


\section{Results}

The lowest concentration of urea (Table 2) was determined in lactating ewes in group 1 (without Se); significantly higher urea concentrations $(P<0.01 ; P<0.05)$ were found in group 3 (sodium selenite) and group 2 (Selplex $\left.{ }^{\circledR}\right)$, respectively. In addition, it is evident from Table 2 that the addition of inorganic selenium (group 3 ) to the feed mixture of ewes in lactation significantly affected $(P<0.05)$ the lowering of cholesterol in relation to the group of ewes with the addition of organic selenium (group 2) and the

Table 2. Biochemical indicators in the blood of highly pregnant and lactating ewes

\begin{tabular}{|c|c|c|c|c|c|c|c|c|}
\hline \multirow{3}{*}{ Indicator } & \multicolumn{5}{|c|}{ Group } & \multirow{3}{*}{$\begin{array}{c}P \text { value } \\
\text { R.S. }\end{array}$} & \multirow{3}{*}{$\begin{array}{l}P \text { value } \\
\text { R.S.xG. }\end{array}$} & \multirow{3}{*}{$P$ value } \\
\hline & $\mathrm{R}$. & 1 & 2 & 3 & SEM & & & \\
\hline & S. & Mean & Mean & Mean & Group & & & \\
\hline \multirow{2}{*}{$\begin{array}{l}\text { Glucose, } \\
\mathrm{mmol} / 1\end{array}$} & L.P. & 3.47 & 3.78 & 3.48 & 0.09 & \multirow{2}{*}{0.378} & \multirow{2}{*}{$<0.01$} & \multirow{2}{*}{0.158} \\
\hline & L. & 3.99 & 4.11 & 4.39 & 0.10 & & & \\
\hline \multirow{2}{*}{$\begin{array}{l}\text { Urea, } \\
\mathrm{mmol} / 1\end{array}$} & L.P. & 9.55 & 9.79 & 8.76 & 0.23 & \multirow{2}{*}{0.033} & \multirow{2}{*}{0.020} & \multirow{2}{*}{$<0.01$} \\
\hline & L. & $8.52^{\mathrm{Aa}}$ & $10.38^{\mathrm{b}}$ & $12.15^{\mathrm{B}}$ & 0.44 & & & \\
\hline \multirow{2}{*}{$\begin{array}{l}\text { Cholesterol, } \\
\mathrm{mmol} / \mathrm{l}\end{array}$} & L.P. & 1.69 & 1.60 & 1.65 & 0.05 & \multirow{2}{*}{0.057} & \multirow{2}{*}{0.151} & \multirow{2}{*}{0.057} \\
\hline & L. & $1.68^{\mathrm{a}}$ & $1.64^{\mathrm{a}}$ & $1.34^{\mathrm{b}}$ & 0.06 & & & \\
\hline \multirow{2}{*}{$\begin{array}{l}\text { Triglycerides, } \\
\mathrm{mmol} / 1\end{array}$} & L.P. & 0.29 & 0.28 & 0.28 & 1.27 & \multirow{2}{*}{0.005} & \multirow{2}{*}{$<0.01$} & \multirow{2}{*}{0.058} \\
\hline & L. & $0.20^{\mathrm{a}}$ & $0.27^{\mathrm{bA}}$ & $0.17^{\mathrm{B}}$ & 0.01 & & & \\
\hline \multirow{2}{*}{$\begin{array}{l}\text { Total } \\
\text { protein, g/1 }\end{array}$} & L.P. & 75.02 & 74.52 & 69.96 & 1.02 & \multirow{2}{*}{0.025} & \multirow{2}{*}{0.850} & \multirow{2}{*}{0.907} \\
\hline & L. & 76.07 & 74.30 & 69.87 & 1.22 & & & \\
\hline \multirow{2}{*}{$\begin{array}{l}\text { Albumin, } \\
\mathrm{g} / 1\end{array}$} & L.P. & 31.50 & 32.52 & 32.69 & 0.64 & \multirow{2}{*}{0.641} & \multirow{2}{*}{0.245} & 0.925 \\
\hline & L. & 30.25 & 31.73 & 30.84 & 1.05 & & & \\
\hline Globulins, & L.P. & 43.51 & 42.00 & 37.20 & 1.40 & 0.369 & 0.420 & 0.928 \\
\hline $\mathrm{g} / 1$ & L. & 45.83 & 42.57 & 39.03 & 1.74 & & & \\
\hline HDL, & L.P. & 0.84 & 0.80 & 0.87 & 0.03 & 0.641 & 0.476 & 0.107 \\
\hline $\mathrm{mmol} / \mathrm{l}$ & L. & 0.82 & 0.95 & 0.83 & 0.03 & & & \\
\hline LDL, & L.P. & 0.72 & 0.68 & 0.65 & 0.03 & 0.204 & 0.119 & 0.012 \\
\hline $\mathrm{mmol} / \mathrm{l}$ & L. & $0.77^{\mathrm{a}}$ & $0.57^{\mathrm{ab}}$ & $0.44^{\mathrm{b}}$ & 0.05 & & & \\
\hline Total bilirubin, & L.P. & 3.00 & 3.00 & 2.42 & 0.14 & 0.071 & 0.034 & 0.171 \\
\hline$\mu \mathrm{mol} / 1$ & L. & 2.91 & 3.64 & 3.00 & 0.17 & & & \\
\hline AST, & L.P & $123.50^{\mathrm{A}}$ & $194.73^{\mathrm{B}}$ & $120.17^{\mathrm{A}}$ & 11.59 & $<0.01$ & 0.276 & $<0.01$ \\
\hline $\mathrm{U} / 1$ & L. & $182.82^{\mathrm{ab}}$ & $265.17^{\mathrm{a}}$ & $161.83^{b}$ & 19.00 & & & \\
\hline ALT, & L.P & 15.08 & 14.17 & 12.58 & 0.52 & 0.344 & 0.210 & 0.251 \\
\hline $\mathrm{U} / 1$ & L. & 18.92 & 13.73 & 14.58 & 1.48 & & & \\
\hline GGT, & L.P & 56.75 & 63.67 & 68.25 & 2.78 & 0.233 & 0.010 & 0.247 \\
\hline $\mathrm{U} / 1$ & L. & 65.91 & 101.18 & 83.92 & 8.14 & & & \\
\hline ALP, & L.P & 128.67 & 170.75 & 136.42 & 12.65 & 0.228 & 0.042 & 0.219 \\
\hline $\mathrm{U} / 1$ & L. & 156.00 & 210.52 & 136.92 & 16.08 & & & \\
\hline $\mathrm{CK}$ & L.P. & 189.17 & 184.92 & 104.50 & 31.79 & 0.333 & 0.250 & 0.670 \\
\hline $\mathrm{U} / 1$ & L. & 126.91 & 123.00 & 107.67 & 12.68 & & & \\
\hline
\end{tabular}

Mean = mean value; SEM = standard error of the mean; R. S. = reproduction status; 1 - control group; 2 - addition of Selplex $^{\circledR} ; 3$ - addition of sodium selenite; L. P. - late pregnancy; L.-lactation; ${ }^{\mathrm{a}, \mathrm{b}} P<0.05 ;{ }^{\mathrm{A}, \mathrm{B}} P<0.01$ differences between treatments; HDL - high density lipoprotein; LDL - low density lipoprotein; AST - aspartate transaminase; ALT - alanine transaminase; GGT - gamma-glutamyl transferase; ALP - alkaline phosphatase; CK - creatine kinase 
control group 1. Also, in the lactating ewes, the lowest concentration of triglycerides was determined in group 3 , i.e. significantly $(P<0.01 ; P<0.05)$ lower than in group 2 and group 1, respectively. In the blood of lactating ewes fed a feed mixture with the addition of inorganic selenium, significantly lower $(P<0.05)$ concentrations of LDL cholesterol were determined compared to the control group without the addition of selenium. The addition of selenium significantly $(P<0.01 ; P<0.05)$ influenced the AST activity. The addition of organic selenium (group 2 ) to the feed mixture of heavily pregnant ewes significantly $(P<0.01)$ increased the AST activity in comparison to groups 1 and 3 . In the lactating ewes, significant $(P<0.05)$ differences in the AST activity were determined between groups 2 and 3. The organic form of selenium significantly increased the AST activity. All the determined enzymes were within the normal reference range.

Table 3. Concentration of minerals in the blood of heavily pregnant and lactating ewes.

\begin{tabular}{|c|c|c|c|c|c|c|c|c|}
\hline \multirow{3}{*}{ Indicator } & \multicolumn{5}{|c|}{ Group } & \multirow{3}{*}{$\begin{array}{c}P \text { value } \\
\text { R.S. }\end{array}$} & \multirow{3}{*}{$\begin{array}{l}P \text { value } \\
\text { R.S.xG. }\end{array}$} & \multirow{3}{*}{$P$ value } \\
\hline & $\mathrm{R}$. & 1 & 2 & 3 & SEM & & & \\
\hline & S. & Mean & Mean & Mean & Group & & & \\
\hline$\overline{\mathrm{Se}}$, & L.P & $96.86^{\mathrm{A}}$ & $157.56^{\mathrm{B}}$ & $141.01^{\mathrm{C}}$ & 5.71 & $<0.001$ & 0.073 & 0.666 \\
\hline$\mu \mathrm{g} / 1$ & L. & $93.37^{\mathrm{A}}$ & $143.18^{\mathrm{Ba}}$ & $131.37^{\mathrm{Bb}}$ & 4.79 & & & \\
\hline \multirow[t]{2}{*}{$\mathrm{Ca} \mathrm{mmol} / \mathrm{l}$} & L.P. & 2.47 & 2.71 & 2.66 & 0.03 & 0.211 & 0.256 & 0.246 \\
\hline & $\mathrm{L}$. & 2.48 & 2.41 & 2.66 & 0.08 & & & \\
\hline \multirow[t]{2}{*}{$\mathrm{P}, \mathrm{mmol} / 1$} & L.P. & 1.83 & 2.04 & 1.99 & 0.05 & 0.828 & 0.105 & 0.004 \\
\hline & L. & 2.30 & 1.93 & 1.98 & 0.08 & & & \\
\hline \multirow[t]{2}{*}{$\mathrm{K}$ mmol/1 } & L.P. & 5.30 & 5.23 & 5.00 & 0.06 & $<0.01$ & 0.096 & 0.129 \\
\hline & L. & $5.03^{\mathrm{A}}$ & $5.33^{\mathrm{A}}$ & $4.75^{\mathrm{B}}$ & 0.07 & & & \\
\hline \multirow[t]{2}{*}{$\mathrm{Na}, \mathrm{mmol} / 1$} & L.P. & 150.83 & 151.25 & 152.08 & 0.41 & 0.038 & 0.724 & 0.685 \\
\hline & L. & $149.82^{\mathrm{a}}$ & $151.50^{\mathrm{ab}}$ & $152.17^{b}$ & 0.44 & & & \\
\hline $\mathrm{Cl}$, & L.P. & $109.75^{\mathrm{a}}$ & $109.17^{\mathrm{A}}$ & $111.67^{\mathrm{Bb}}$ & 0.40 & 0.265 & 0.022 & 0.612 \\
\hline $\mathrm{mmol} / \mathrm{l}$ & L. & 104.82 & 98.50 & 107.00 & 2.75 & & & \\
\hline \multirow[t]{2}{*}{$\mathrm{Fe}, \mu \mathrm{mol} / 1$} & L.P. & 27.76 & 31.73 & 32.73 & 1.26 & 0.01 & 0.857 & 0.443 \\
\hline & L. & $25.32^{\mathrm{Aa}}$ & $32.45^{\mathrm{b}}$ & $33.87^{\mathrm{B}}$ & 1.41 & & & \\
\hline
\end{tabular}

Mean = mean value; $\mathrm{SEM}=$ standard error of the mean; R. S. = reproduction status; 1 - control group; 2 - addition of Selplex ${ }^{\circledR} ; 3$ - addition of sodium selenite; L. P. - late pregnancy; L.-lactation; ${ }^{\mathrm{a}, \mathrm{b}} P<0.05 ;{ }^{\mathrm{A}, \mathrm{B}} P<0.01$; Se selenium; $\mathrm{Ca}$ - calcium; $\mathrm{P}$ - phosphorus; $\mathrm{K}$ - potassium; $\mathrm{Na}$ - sodium; $\mathrm{Cl}$ - chlorine; $\mathrm{Fe}$ - iron

Selenium supplementation of the feed mixture of heavily pregnant and lactating ewes had a significant effect on its concentration in the blood. In the blood of heavily pregnant and lactating ewes, a significantly higher $(P<0.01)$ concentration of Se was determined in groups 2 and 3 compared to control group 1. The highest Se concentration in the blood of heavily pregnant sheep was found in the group fed with the addition of organic selenium, and significant $(P<0.01 ; P<0.05)$ differences were also established between groups 2 and 3 , respectively (Table 3 ). In addition, in lactating ewes, the highest concentration of selenium was determined in group 2. It is evident that the addition of selenium to the ewes' feed mixture affected the changes in concentration of most minerals in their blood, but most often, the differences were not significant (Table 3). In lactating ewes the lowest $\mathrm{Na}$ concentration was determined in the first group and was significantly $(P<0.05)$ lower than in group 3 and lower compared to group 2 . Significantly $(P<0.05)$ decreased $\mathrm{K}$ concentration was determined in group 3 . The $\mathrm{Cl}$ concentration in heavily pregnant ewes was the highest in group 3 , where it was significantly higher $(P<0.0 ; P<0.05)$ compared 
to group 2 and 1, respectively. The lowest Fe concentration was found in the control group of the lactating ewes; significantly higher $(P<0.01 ; P<0.05)$ Fe concentration was found in group 3 and 2, respectively, with the addition of inorganic or organic selenium.

Table 4. Concentration of thyroid hormones in blood serum of heavily pregnant and lactating ewes.

\begin{tabular}{|c|c|c|c|c|c|c|c|c|}
\hline \multirow{3}{*}{ Indicator } & \multicolumn{5}{|c|}{ Group } & \multirow{3}{*}{$\begin{array}{c}P \text { value } \\
\text { R.S. }\end{array}$} & \multirow{3}{*}{$\begin{array}{l}P \text { value } \\
\text { R.S.xG. }\end{array}$} & \multirow{3}{*}{$P$ value } \\
\hline & R. & 1 & 2 & 3 & SEM & & & \\
\hline & S. & Mean & Mean & Mean & Group & & & \\
\hline$\overline{\mathrm{T}_{3}}$, & L.P. & 0.85 & 1.26 & 1.02 & 0.11 & 0.05 & 0.023 & 0.193 \\
\hline$\mu \mathrm{mol} / 1$ & L. & $1.18^{\mathrm{a}}$ & 1.32 & $1.76^{\mathrm{b}}$ & 0.09 & & & \\
\hline $\mathrm{T}_{4}$ & L.P. & 69.19 & 74.33 & 79.47 & 4.35 & 0.33 & 0.04 & 0.58 \\
\hline$\mu \mathrm{mol} / 1$ & L. & 82.76 & 79.15 & 97.68 & 4.68 & & & \\
\hline
\end{tabular}

Mean = mean value; SEM = standard error of the mean; R. S. = reproduction status; 1 - control group; 2 - addition of Selplex ${ }^{\circledR} ; 3$ - addition of sodium selenite; L. P. - late pregnancy; L.-lactation; ${ }^{\text {a,b }} P<0.05$; differences between treatments

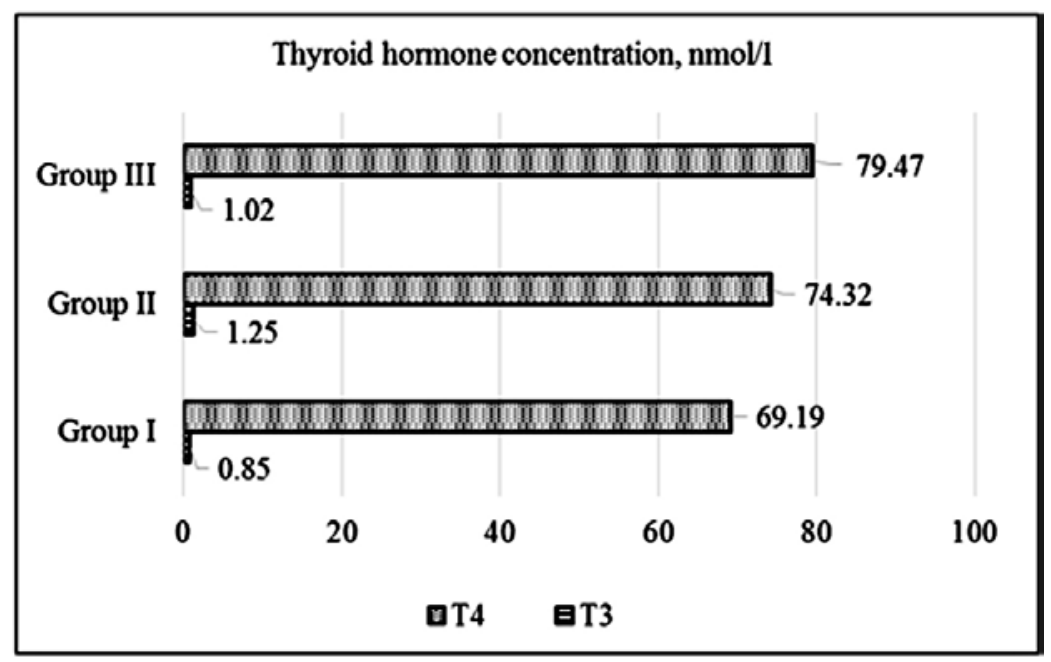

Fig. 1. Concentration of thyroid hormones in blood serum of late pregnant ewes. I - control group; II - addition of Selplex ${ }^{\circledR}$; III - addition of sodium selenite

Analysing Table 4 and Fig. 1 we can see that the concentration of $\mathrm{T}_{3}$ and $\mathrm{T}_{4}$, as well as ratio $\mathrm{T}_{3} / \mathrm{T}_{4}$, were comparable $(P>0.05)$ except for the concentration of $\mathrm{T}_{3}$ hormone in lactating ewes which was significantly $(P<0.05)$ higher in group 3 (Fig. 2). The mean values of the $\mathrm{T}_{3} / \mathrm{T}_{4}$ ratio were non-significant $(P>0.05)$, but showing a numerically higher value (Fig. 3).

\section{Biochemical indicators}

\section{Discussion}

Although the influence was not significant, Chung et al. (2007) found an increase of glucose concentration and decrease of total protein, cholesterol and triglyceride in goats fed a feed mixture with the addition of $0.25 \mathrm{ppm}$ of organic or inorganic selenium, which is in accordance with this research. Nutrition has the greatest impact on the concentration 


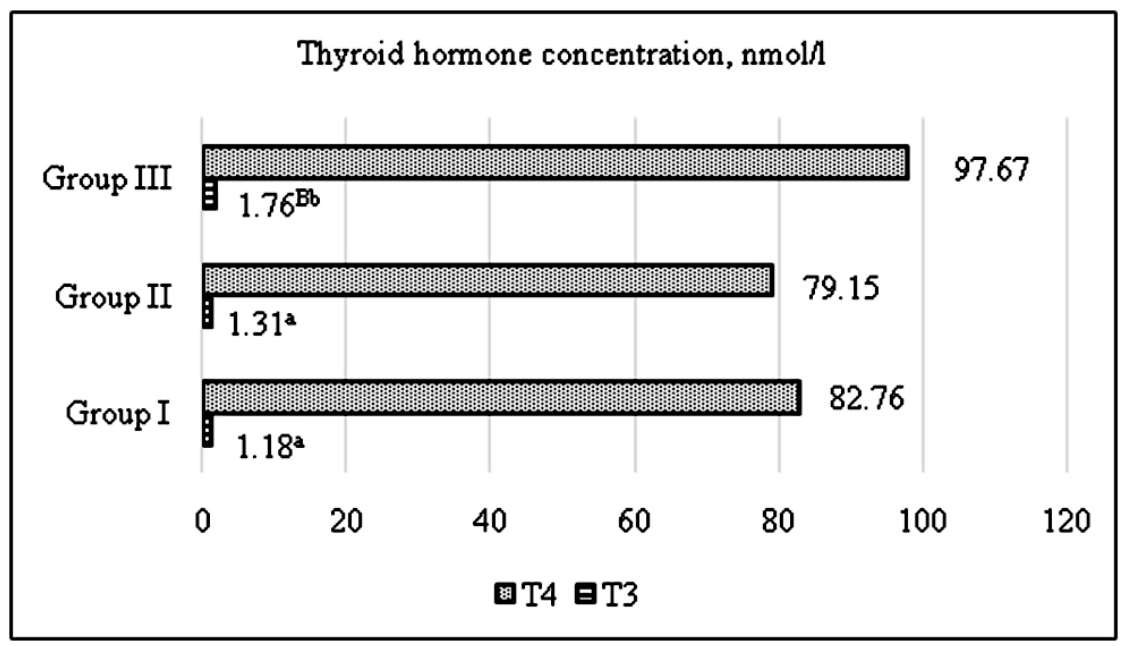

Fig. 2. Concentration of thyroid hormones in blood serum of lactation ewes I - control group; II - addition of Selplex ${ }^{\mathbb{\circledR}}$; III - addition of sodium selenite; a,b, $P<0.05 ;{ }^{\mathrm{A}, \mathrm{B}} P<0.01$

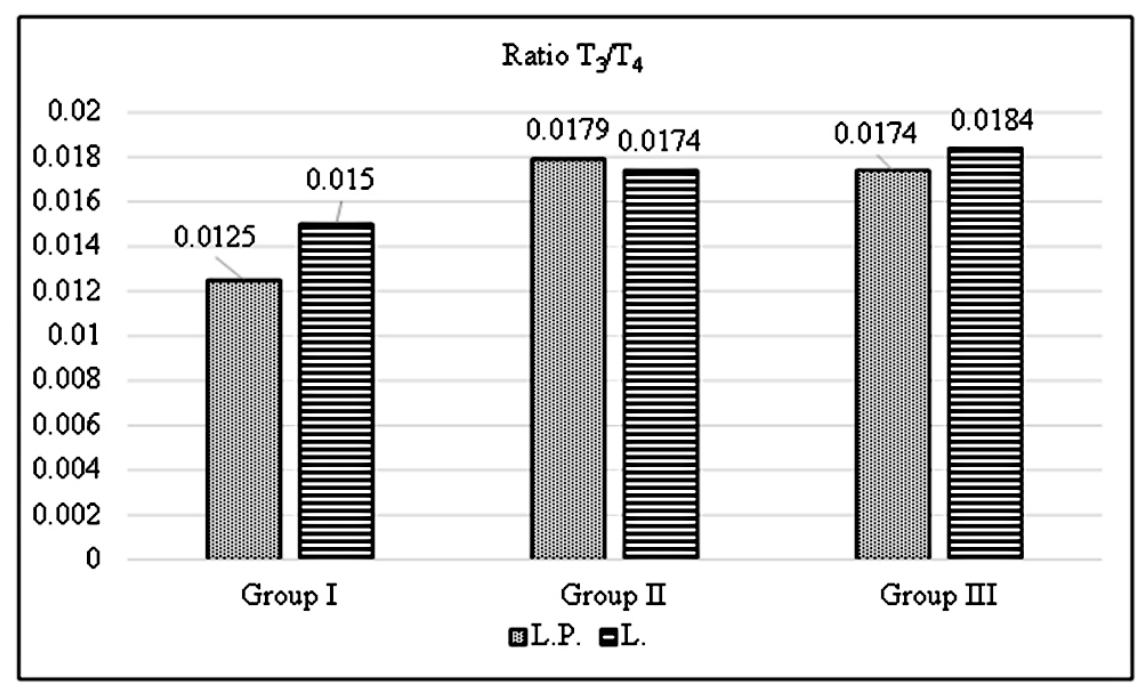

Fig. 3. Ratio of $\mathrm{T}_{3} / \mathrm{T}_{4}$ hormoneS

I - control group; II - addition of Selplex ${ }^{\circledR}$; III - addition of sodium selenite; L. P. - late pregnancy; L.-lactation;

of glucose and urea in the blood of ewes. Restrictions in nutrition, especially during late pregnancy lead to a drop of glucose concentration in blood (Lekatz et al. 2011). In the present study, selenium sources had no effect on blood glucose, total protein, albumin, and globulin which is in accordance with results of the study of Sethy et al. (2015) carried out on goats. In this research, glucose was within the reference range, indicating adequate nutrition. A significant $(P<0.05)$ increase in blood urea concentrations of cows fed a mineral supplement in the form of sodium selenite was observed by Slavik et al. (2008). 
Significant changes in the concentration of urea in the blood of cows after treatment with selenium were determined by Juniper et al. (2006). The concentration of blood urea is the main nitrogen indicator of amino acid catabolism. The significant increase of urea concentration in blood of lactating ewes determined in this study is probably linked to the catabolism of amino acids, or the stress the ewes are under at the beginning of the lactation period. The higher urea concentration, which was above the reference value, indicates the fact that the ration was rich in protein. It is known that the concentration of urea in the blood can be taken as a reliable indicator of the protein content in the ration of ewes (Whitney et al. 2009).

It is considered that the impact of nutritional antioxidants in food on blood biochemical indices depends on the amount of selenium in foods, fat content in food, reproductive condition, and the form of added selenium. Establishing the preventive effect of selenium on atherosclerosis (Scott et al. 1991) prompted a number of studies aimed at understanding the relationship between antioxidants and blood cholesterol levels. Kang et al. (1998) and Lizuka et al. (2001) found in rats that were fed high cholesterol level rations with the addition of selenium, lower concentrations of triglycerides, cholesterol and free fatty acids in their blood serum. In our research, we also determined a significant decrease $(P<0.05)$ of cholesterol and triglyceride level in group 3 of the lactating ewes. A similar concentration of albumin in the serum of sheep, as well as in this study, was found by Davis et al. (2007) upon the addition of $0.2 \mathrm{mg} / \mathrm{kg}$ selenium as sodium selenite and selenium yeast. The same authors found that sodium selenite significantly increased $(P<0.05)$ the concentration of albumin. In this study slightly higher concentrations of albumin (32.52: $32.69 \mathrm{~g} / \mathrm{l}$ ) were found, which is probably related to the greater amount of selenium $(0.3 \mathrm{mg} / \mathrm{kg})$ added to the ewes' feed. A smaller increase in the concentration of albumin was also established, but without significant differences between groups. Juniper et al. (2008) found in ruminants that organic selenium, i.e. selenized yeast, increased the concentration of albumin, and decreased the concentration of globulin and total protein with no significant difference, which is in line with the results of our study. In their study, selenized yeast had no significant effect on the concentration of glucose, which is in accordance with our results. In a study conducted by Malecki et al. (2002) on the Suffolk breed of ewes in the third month of pregnancy, the addition of inorganic selenium was found to have significantly $(P<0.05)$ increased the concentration of urea and glucose in the blood serum, whereas in our study the increasing tendency was determined, but without a significant difference. Similar to our study, Panev et al. (2013) found no significant influence of different sources (organic : inorganic) and contents of Se in the feed mixture of ewes on the concentration of albumin and total bilirubin. Singh et al. (2002) and Shashidhar and Prasad (1993) observed an increased AST activity when they supplemented buffalo calves with $8.54 \mathrm{ppm}$ Se, and adult goats with $0.15-0.3 \mathrm{mg} \mathrm{Se}$ per $\mathrm{kg}$ body weight, respectively. However, Mudgal et al. (2008) and Kumar et al. (2009) also did not find any effect of selenium supplementation $(0.3 \mathrm{ppm})$ on serum AST enzyme level in buffalo calves and lambs. Elevated serum AST and LDH activity has been reported in nutritional muscular dystrophy which is caused by Se deficiency in lambs and calves, and partly results from enhanced tissue damage due to lipid peroxidation. Gehringer et al. (2003) reported that dietary Se protected against toxins, leading to decreased serum ALT and lipid peroxidation levels.

\section{Concentration of minerals}

The concentration of selenium in the body depends on its content in the diets as observed by Cristaldi et al. (2005). According to previous studies (Pavlata et al. 2011; Hall et al. 2012; Antunović et al. 2013; Faixova et al. 2016) it is more efficient to utilize organic sources of Se compared to inorganic, as also demonstrated in the present study. 
The optimal Se concentration in the blood serum of ewes is $120-150 \mu \mathrm{g} / \mathrm{l}$ (Hefnawy et al. 2007), whereas the values ranging between $25-50 \mu \mathrm{g} / \mathrm{l}$ are considered deficient (Øverneset al. 1985). Serum Se concentrations during late pregnancy and lactation determined in the control group in the present study indicate that ewes raised in this region had physiologically low, almost deficient Se concentrations. These findings are similar to the study of Erdoğan et al. (2017). Comparing the obtained concentration of $\mathrm{Ca}, \mathrm{P}, \mathrm{Na}$, and $\mathrm{Fe}$ with the reference values for ewes (Kaneko et al. 2008) showed that they were within the reference range, except for $\mathrm{Cl}$, the concentration of which was slightly higher. Malecki et al. (2002) found a significant $(P<0.05)$ decrease of the $\mathrm{Ca}$ concentration in ewes which received sodium selenite by injection. However, they determined an increase in the $\mathrm{P}$ concentration in a group of ewes, which received Se, compared to control $(2.30: 2.14)$. $\mathrm{Hu}$ and Murphy (2004) noted that the $\mathrm{Cl}$ concentration is most dependent on the nutrient intake. A constant $\mathrm{K}$ concentration is a prerequisite for homeostasis, since a substantial fluctuation in the content of this electrolyte may lead to structural and functional disorders of e.g., the cardiac muscle, smooth muscles, and skeletal muscles (Williams et al. 2004). Jalilian et al. (2012) found in pregnant Sanjabi ewes supplemented with sodium selenite and vitamin $\mathrm{E}$ by injection and increasing tendency of $\mathrm{Fe}$, but with no significant difference, which is in accordance with our study. In late pregnancy and early lactation, many authors determined lower concentrations of minerals, the reason for which may be an increased secretion of electrolytes with milk; in our study, we determined the opposite trend.

\section{Thyroid hormones}

According to Aurthor et al. (1992), Se is an essential element for normal metabolism of the thyroid hormones. Compared to Se-supplemented calves, Se-deficient calves had increased plasma $T_{4}$ and decreased plasma $T_{3}$ concentrations. Studies in animals have shown serum concentrations of $\mathrm{T}_{3}$ and $\mathrm{Se}$ to be positively correlated (Arthur and Becket 1988) and Se deprivation to increase circulating concentrations of $\mathrm{T}_{4}$ and/or decrease those of $\mathrm{T}_{3}$ (Zimmerman and Köhrle 2002). Increased $\mathrm{T}_{3}$ concentration can be explained by increased activity of enzyme type 4 deiodinase in the conversion of thyroxine $\mathrm{T}_{4}$ into the more active triiodothyronine $T_{3}$ and is in positive correlation with energy and nitrogen balance ration. Shinde et al. (2009) showed significantly higher activity of $\mathrm{T}_{3}$ hormone in the blood of buffalo calves that were fed with the addition of Se (sodium selenite), compared to those without added Se. Similarly Nayyar et al. (2003) also reported that buffalo heifers that were supplemented with Se had significantly $(P<0.05)$ higher $\mathrm{T}_{3}$ concentrations compared to unsupplemented control animals. Dominguez-Vara et al. (2009) observed increased plasma $T_{3}$ concentration in Rambouillet sheep supplemented with $0.3 \mathrm{ppm}$ organic Se for 95 days. El-Shah at and Monem (2011) found no significant differences between concentrations of $\mathrm{T}_{3}$ and $\mathrm{T}_{4}$ hormones in Egyptian Baladi ewes under subtropical conditions when supplemented only with Se. Significantly, higher $\mathrm{T}_{4}$ concentrations was determined when ewes were supplemented with vitamin $\mathrm{E}_{2}, \mathrm{Se}+$ vit $\mathrm{E}_{1}^{4}$ and $\mathrm{Se}+$ vit $\mathrm{E}_{2}$.

Supplementation of ewes with selenium (organic or inorganic) is essential to increase and maintain the concentration of selenium in blood and has a protective role against nutritional muscular dystrophy. In ewes, addition of Se to the feed mixture had a significant influence on urea concentration, level of cholesterol, LDL and triglycerides as well as the concentration of $\mathrm{Na}, \mathrm{K}, \mathrm{Cl}$, and $\mathrm{Fe}$. Selenium has influenced the thyroid hormone which is a sign of a good energy and nitrogen balance of the ration as well as an intensive metabolic process. Based on results we can conclude that Se positively influenced some biochemical indicators as well as minerals or helped shift their value to the reference range. Selenium supplementation contributes to good health and condition of ewes in the demanding period 
of lactation when certain metabolic disorders can occur, raising or reducing the values of some indicators in the ewes' blood. The results indicate a lack of Se in the blood of ewes of the control group and the justification of adding Se to the ewes' diets in Se-deficient areas.

\section{References}

Antunović Z, Marić I, Matanić I, Senčić Đ, Šperanda M, Novoselec J 2009: Blood enzymes and thyroid hormone activity for the assessment of selenium supply in sheep (in Croatian). Krmiva 51: 131-137

Antunović Z, Novoselec J, Šperanda M, Đidara M, Klir Ž, Kopačin T 2011: Blood acid base balance and hematological parameters in pregnant goats from organic farming. Krmiva 53: 151-156

Antunović Z, Novoselec J, Šperanda M, Klapec T, Ćavar S, Mioč B, Klir Ž, Pavić V, Vuković R 2013: influence of dietary supplementation with selenium on blood metabolic profile and thyroid hormones activities in fattening lambs. Pak Vet J 34: 224-228

Arthur JR, Beckett GJ 1988: Selenium deficiency and thyroid hormone metabolism. In (Springer-Verlag): Selenium in biology and medicine. New York, NY: pp 90-95

Aurthor JR, Nicol F, Beckett GJ 1992: The role of selenium in thyroid hormone metabolism and effect of selenium deficiency on thyroid hormones and iodine metabolism. Biol Trace Elem Res 33: 37-42

Awadeh FT, Kincaid RL, Johnson KA 1998: Effect of level and source of dietary selenium on concentrations of thyroid hormones and immunoglobulins in beef cows and calves. J Anim Sci 76: 1204-1215

Chung JY, Kim JH, Ko YH, Jang IS 2007: Effect of dietary supplemented inorganic and organic selenium on antioxidant defense systems in the intestine, serum, liver, and muscle of Korean native goats. Asian-Australas J Anim Sci 20: 52-59

Cristaldi LA, McDowell RL, Buergelt CD, Davis PA, Wilkinson NS, Martin FG 2005: Tolerance of inorganic selenium in wether sheep. Small Rumin Res 56: 205-213

Davis PA, McDowell LR, Wilkinson NS, Buergelt CD, Van Alstyne R, Weldon RN, Marshall TT, MatsudaFugisaki EY 2007: Coarative effects of various dietary levels of Se as sodium selenite or Se yest on blood, wool, and tissue Se concentration of wether sheep. Small Rumin Res 74: 149-158

Dominguez-Vara IA, Gonzalez-Munoz SS, Pinos-Rodriguez JM, Borquez-Gastelum JL, Barcena-Gama R, Mendoza-Martinez G, Zapata LE, Landois-Palencia LL 2009: Effects of feeding selenium-yeast and chromiumyeast to finishing lambs on growth, carcass characteristics, and blood hormones and metabolites. Anim Feed Sci Technol 152: 42-49

El-Shahat KH, Abdel Monem UM 2011: Effects of dietary supplementation with vitamin E and /or selenium on metabolic and reproductive performance of Egyptian Baladi ewes under subtropical conditions. World Appl Sci J 12: 1492-1499

Erdoğan S, Karadaş F, Yılmaz A, Karaca S 2017: The effect of organic selenium in feeding of ewes in late pregnancy on selenium transfer to progeny. R Bras Zootec 46: 147-155

Faixova Z, Piešova E, Makova Z, Čobanova K, Faix Š 2016: Effect of dietary supplemenatation with seleniumenriched yeast or sodium selenite on ruminal enzyme activities and blood chemistry in sheep. Acta Vet Brno 85: $185-194$

Gehringer MM, Down KS, Downing TG, Naude RJ, Shephard EG 2003: An investigation into the effect of selenium supplementation on microcystin hepatotoxicity. Toxicon 41: 451-458

Hall JA, Van Saun RJ, Bobe G, Stewart WC, Vorachek WR, Mosher WD, Nichols T, Forsberg NE, Pirelli GJ 2012: Organic and inorganic selenium: I. Oral bioavailability in ewes. J Anim Sci 90: 568-576

Hefnawy AE, López-Arellano AE, Revilla-Vázquez R, Ramírez-Bribiesca A, Tórtora-Pérez J L 2007: Interrelationship between fetal and maternal selenium concentrations in small ruminants. Small Rumin Res 73: $174-180$

$\mathrm{Hu}$ W, Murphy MR 2004: Dietary cation-anion difference effects on performance and acid-base status of lactating dairy cows: a meta-analysis. J Dairy Sci 87: 2222-2229

Jalilian MT, Moeini MM, Karkodi K 2012: Effect of selenium and vitamine E supplementation during late pregnancy on colostrum and plasma $\mathrm{Se}, \mathrm{Cu}, \mathrm{Zn}$, and Fe concentrations of fat tail Sanjabi ewes and their lambs. Acta Agric Slov 100: 123-129

Juniper DT, Phipps RH, Jones AK, Bertin G 2006: Selenium supplementation of lactating cows: Effect on selenium concentration in blood, milk, urine and feces. J Dairy Sci 89: 3544-3551

Juniper DT, Phipps RH, Givens DI, Jones AK, Green C, Bertin G 2008: Tolerance of ruminant animals to high dose in-feed administration of a selenium-enriched yeast. J Anim Sci 86: 197-204

Kaneko JJ, Harvey JW, Bruss ML 2008: Clinical Biochemistry of Domestic Animals. ${ }^{\text {th }}$ ed. Elsevier/ Academic Press, Amsterdam, 932 p.

Kang BP, Bansal MP, Mehta U 1998: Selenium supplementation and diet induced hypercholesterolemis in the rat: changes in lipid levels, malonyldialdehyde production and the nitric oxide synthase activity. Gen Physiol Biophys 17: 71-78 
Kumar N, Garg, AK, Dass, RS, Chaturvedi VK, Mudgal V, Varshney VP 2009: Selenium supplementation influences growth performance, antioxidant status and immune response in lambs. Anim Feed Sci Technol 153: $77-87$

Lekatz LA, Wu G, Caton JS, Taylor JB, Reynolds LP, Redmer DA, Vonnahme KA 2011: Maternal selenium supplementation and timing of nutrient restriction in pregnant sheep: Impacts on nutrient availability to the fetus. J Anim Sci 89: 59-76

Lizuka YE, Sakurai and Tanaka Y 2001: Effect of selenium on serum, hepatic and lipoprotein lipids concentration in rats fed on a high-cholesterol diet. Yakugaku Zasshi 121: 93-96

Malecki J, Malinowski E, Supera K, Balicka-Ramis A 2002: Influence of selenium with vitamine E and cobalt heavy pellets on reproduction and metabolic profiles of ewes. EJPAU 5: 05

Mudgal V, Garg AK, Dass RS, Varshney VP 2008: Effect of selenium and copper supplementation on blood metabolic profile in male buffalo (Bubalus bubalis) Calves. Biol Trace Elem Res 121: 31-38

Nayyar S, Gill VK, Malik VS, Roy KS, Singh R 2003: Vitamin E and selenium improve the blood biochemical composition of anoestrous buffalo heifers. Indian J Anim Sci 73: 654-656.

Panev A, Hauptmanova K, Pavlata L, Pechova A, Filipek J, Dvorak R 2013: Effect of supplementation of various selenium forms and doses on selected parameters of ruminal fluid and blood sheep. Czech J Anim Sci 58: 37-46

Pavlata L, Misurova L, Pechova A, Dvorak R 2011: The effect of inorganic and organically bound forms of selenium on glutathione peroxidase activity in the blood of goats. Vet Med 56: 75-81

Øvernes G, Moksnes K, Froslie A, Gunnar JG, Flaat J 1985: The effect of different levels of selenium in mineral mixtures and salt licks on selenium status in sheep. Acta Vet Scand 26: 405-416

Salman S, Dinse D, Khol-Parisini A, Schafft H, Lahrssen-Wiederholt M, Schreiner M, Scharek-Tedin L, Zentek J 2013: Colostrum and milk selenium, antioxidative capacity and immune status of dairy cows fed sodium selenite or selenium yeast. Arch Anim Nutr 67: 48-61

SAS $9.3^{\circledR}$, SAS Institute Inc., Cary, NC, USA

Scott RL, Kheshti A, Heimberg M, Wilcox GH, Stone WL 1991: The role of selenium in the secretion of very-low density lipoprotein in the isolated perfused rat liver. Biochem J 279: 741-745

Sethy K, Dass RS, Garg AK, Sahu S, Gogoi S 2015: Effect of different selenium sources (selenium yeast and sodium selenite) on haematology, blood chemistry and thyroid hormone sin male goat (Capra hircus). Indian J Anim Res 49: 788-792

Shashidhar G, Prasad T 1993: Influence of selenite and selenomethionin administration on serum transaminases and hematology of goats. Indian J Anim Nutr 10:1-6

Shinde PL, Dass RS, Garg AK 2009: Effect of vitamin E and selenium supplementation on haematology, blood chemistry and thyroid hormones in male buffalo (Bubalus bubalis) calves J Anim Feed Sci 18: 241-256

Singh R, Randhawa SS, Dhillon KS 2002: Changes in blood biochemical and enzyme profile in experimental chronic selenosis in buffalo calves (Bubalus bubalis). Indian J Anim Sci 72: 230-232

Slavik R, Illek J, Brix M, Hlavicova J, Rajmon R, Jilek F 2008: Influence of organic versus inorganic dietary selenium supplementation on the concentration of seleniumin colostrum, milk, and blood of beef cows. Acta Vet Scand 50: 43-53

Vignola G, Lambertini M, Giammarco P, Pezzi P, Mazzone G. 2007: Effect of Se supplementation on growth rate and blood parameters in lambs. Ital J Anim Sci 6: 383-385

Whitney TR, Waldron DF, Willingham TD 2009: Evaluating nutritional status of Dorper and Rambouillet ewes in range sheep production. Sheep Goat Res J 24: 10-16

Williams CC, Calmes KJ, Fernandez JM, Stanley CC, Lovejoy JC, Bateman HG, Gentry LR, Gantt DT, Harding GD 2004: Glucose metabolism and insulin sensitivity in Gulf Coast Native and Suffolk ewes during late gestation and early lactation. Small Rumin Res 54: 167-171

Zimmerman MB, Köhrle J 2002: The impact of iron and selenium deficiency on iodine and thyroid metabolism: biochemistry and relevance to public health. Thyroid 12: 867-878 